\title{
Distinct effects of the antiestrogen Faslodex on the stability of estrogen receptors- $\alpha$ and $-\beta$ in the breast cancer cell line MCF-7
}

\author{
N T Peekhaus, T Chang, E C Hayes, H A Wilkinson, S W Mitra, J M Schaeffer and \\ S P Rohrer
}

Department of Atherosclerosis and Endocrinology, Merck Research Laboratories, Rahway, New Jersey 07065, USA

(Requests for offprints should be addressed to N T Peekhaus; Email: norbert_peekhaus@merck.com)

\begin{abstract}
The effects of estrogen receptor (ER) ligands on the stability and transcriptional activity of ER $\beta$ in the breast cancer cell lines MCF-7 and HeLa were examined. We found that ER $\beta$ was degraded in the presence of $17 \beta$-estradiol. Tamoxifen and Faslodex (ICl 182,780) prevented ER $\beta$ receptor destabilization. In contrast to ER $\alpha$, ER $\beta$ degradation was not abolished by inhibitors of the proteasome-mediated protein degradation pathway. Furthermore, single point mutations in helix 12 of the receptor dramatically affected the stability and subsequent transcriptional activation of ER $\beta$.
\end{abstract}

Journal of Molecular Endocrinology (2004) 32, 987-995

\section{Introduction}

Estrogens regulate growth and cellular differentiation in a variety of female tissues, including breast, uterus, bone, cardiovascular systems, and the brain. There are two known estrogen receptor (ER) subtypes, $\mathrm{ER} \alpha$ and $\mathrm{ER} \beta$ (Kuiper et al. 1996, Cowley et al. 1997, Katzenellenbogen \& Katzenellenbogen 2000, Katzenellenbogen et al. 2000). After hormone binding, ERs form dimers, interact with basal transcription factors and numerous co-activators, and bind to estrogen responsive elements (ERE) to effect transcription. ERs can also modulate expression of target genes by interacting indirectly with AP-1, Sp 1, or CRE to modulate expression in a tissue-specific manner. Despite their similar action at EREs where both receptors activate when complexed to $17 \beta$-estradiol (E2), the activation at $\mathrm{AP}-1$ or $\mathrm{Sp}-1$ response elements is somewhat different (Paech et al. 1997, Webb et al. 1999). ER $\alpha$ trans-activates gene transcription via AP- 1 and ER $\beta$ trans-represses. Besides the action of the hormone, the ER concentration is a key component to its responsiveness in different cell tissues. The ER $\alpha$ level changes with the varying physiological state of the tissue and may be regulated by the ligand itself (Read et al. 1989, Preisler-Mashek et al. 2002).

Studies with ER knockout mice have shown that $\mathrm{ER} \alpha$ but not $\mathrm{ER} \beta$ is essential for proliferation in mammary gland, uterus, and prostate (Hewitt \& Korach 2003). E2-stimulated proliferation was shown to be normal in the $\operatorname{ER} \beta$ but absent in the ER $\alpha$ knockout mice (Couse et al. 2001, Hewitt \& Korach 2003). However, even if $\mathrm{ER} \alpha$ is the proliferative inducer in most tissues, a possible impact of $\operatorname{ER} \beta$ on proliferation has been suggested (Couse et al. 2001, Frasor et al. 2003). While the majority of E2 action in the uterus is mediated by $\mathrm{ER} \alpha, \mathrm{ER} \beta$ does play a role in modulating $\mathrm{ER} \alpha$ effectiveness (Weihua et al. 2000) in a dosedependent manner. Additional studies with knockout animals have shown that, in bone, in the absence of $\mathrm{ER} \alpha, \mathrm{ER} \beta$ can stimulate $\mathrm{ER} \alpha$-regulated genes. In the presence of $\operatorname{ER} \alpha, \operatorname{ER} \beta$ almost always reduces the stimulation by ER $\alpha$ (Lindberg et al. 2003). 
It has been proposed that ER $\beta$ modulates the proliferative action of $\operatorname{ER} \alpha$ and negatively affects cell proliferation in breast and uterus (Lazennec et al. 2001). Previous studies have shown that ER $\alpha$ is a short-lived protein with a rapid turnover rate due to proteasome-mediated degradation. In contrast to $\mathrm{ER} \alpha$, there are very limited data available regarding the regulation and stability of $\mathrm{ER} \beta$.

In our study, we have evaluated the influence of ER ligands on the stability and activity of transiently transfected $\mathrm{ER} \beta$ overexpressed in MCF-7 and HeLa cells. We also identified critical amino acids involved in modulating $\mathrm{ER} \beta$ protein stability using mutant forms of the receptor.

\section{Materials and methods}

\section{Reagents}

E2, 4-hydroxytamoxifen (Tam), lactacystin, and insulin were purchased from Sigma (St Louis, MO, USA). ICI 182,780 (Faslodex) was purchased from Tocris Cookson Inc. (Ballwin, MO, USA). Proteasome inhibitor I (PI) was purchased from Calbiochem (San Diego, CA, USA). ER $\beta$ antibody D7N was obtained from Zymed (San Fransisco, CA, USA), ER $\alpha$ antibody Ab-15 from NeoMarkers (Freemont, CA, USA), and $\beta$-actin antibody AC-15 from AbCam (Cambridge, Cambs, UK). Tissue culture reagents such as Hepes, L-glutamine, non-essential amino acids (NEAA), fetal bovine serum (FBS), pheno red-free minimum essential medium (MEM), and penicillin/streptomycin were purchased from Invitrogen (Carlsbad, CA, USA).

\section{Expression and reporter vectors}

AP-1-luc reporter plasmids were a gift from Azi Schmidt (Merck Research Laboratories). ER $\beta$ expression vector phER $\beta w t$ was generated by subcloning a $1.8 \mathrm{~kb} B a m \mathrm{H} 1-A p a \mathrm{I}$ DNA fragment, carrying the full-length human ER $\beta$ cDNA, into vector pCDNA3·1To/myc-HisA (Invitrogen). The resulting construct was sequenced. Two silent mutations were detected within the receptor gene. The $\operatorname{ER} \alpha$ expression vector phER $\alpha$ was constructed by subcloning a $1.9 \mathrm{~kb}$ EcoRI-SpeI DNA fragment, containing the full-length human ER $\alpha$, into pcDNA3 $\cdot 1$.

\section{Mutagenesis}

ER $\beta$ mutants were generated by site-directed mutagenesis using the Quickchange site-directed mutagenesis kit (Stratagene, La Jolla, CA, USA) and the plasmid phER $\beta w$ t was used as template. The following primers were used: D489A (5'-GTG GTCGCAGTGTATGCGCTGCTGCTGGAGA TG-3' and 5'-CATCTCGAGGAGCAGGGGATA CACTGGGA-3'), L491Q (5'-CGAGTGTATGAC CTGCAGCTGGAGATGCTGAATGCC-3' and 5'-GGCATTCAGCATCTCGAGCTGCAGGTC ATACACTGG-3'), E493A (5'-GACGTGGTGCT GGCGATGGTGA-ATGCCGAC-3' and 5'-GTG GGCATTCAGCATGCGCAGCAG-CAGGTC-3').

All constructs were confirmed by sequencing.

\section{Transient transfection and reporter assay}

MCF-7 and HeLa cells were cultured in phenol red-free MEM supplemented with $10 \mathrm{mM}$ Hepes, $2 \mathrm{mM}$ L-glutamine, NEAA, 10\% FBS, and penicillin/streptomycin. Cells were grown to $50-60 \%$ confluency and transfected in 6-well or 12-well plates using lipofectamine-2000 as per the manufacturer's instructions (Invitrogen). For the luciferase reporter assay, $0.5 \mu \mathrm{g}$ expression vector (phER $\beta w$ t and mutant), 1.0 $\mathrm{gg}$ reporter plasmid, and $1 \cdot 0 \mu \mathrm{g}$ normalizing $\beta$-galactosidase plasmid were used. One volume of media with $20 \%$ FBS and compound was added $4 \mathrm{~h}$ after transfection. The media were replaced with fresh media and compound after $12 \mathrm{~h}$ and cells were grown for another $6 \mathrm{~h}$. The cells were harvested, washed twice with PBS, and stored at $-80^{\circ} \mathrm{C}$.

\section{Cell extract and Western blotting}

The frozen cell pellet was resuspended in $200 \mu \mathrm{l}$ cell extraction buffer $(50 \mathrm{mM}$ Tris- $\mathrm{HCl}$, $\mathrm{pH} 8.0$; $0 \cdot 4 \mathrm{M} \mathrm{NaCl} ; 5 \mathrm{mM}$ EDTA; $1 \%$ Nonidet; 0.2\% sarcosyl; $100 \mu \mathrm{M}$ sodium vanadate; $10 \mathrm{mM}$ sodium molybdate; $20 \mathrm{mM} \mathrm{NaF}$ ) containing a 1:100 dilution of protease inhibitor cocktail (Sigma) on ice, passed several times through a small micropipette tip, and incubated on ice for $30 \mathrm{~min}$. The extract was centrifuged at $10500 \boldsymbol{g}$ for $30 \mathrm{~min}$ at $4{ }^{\circ} \mathrm{C}$ and the supernatant was transferred to a new tube. Protein concentration was measured using the BCA protein assay reagent A from Pierce (Rockford, IL, USA). Cell extract was subject to 
SDS-PAGE $(10 \%)$ and transferred to polyvinylidene difluoride membranes. The membranes were blocked with blocking buffer (PBS; 10\% glycerol; $0 \cdot 2 \%$ Tween 20; $10 \%$ non-fat milk) for $1 \mathrm{~h}$. Blots were probed with antibodies overnight at $4{ }^{\circ} \mathrm{C}$. Blots were washed in blocking buffer and incubated with HRP-conjugated anti-rabbit or anti-mouse (Pierce) antibodies. The membranes were washed and developed with Supersignal West Dura ECL substrate (Pierce).

\section{Luciferase assay}

Luciferase and $\beta$-galactosidase activity were measured using luciferase (Promega, Madison, WI, USA) and $\beta$-galactosidase (Applied Biosystems, Bedford, MA, USA) assay kits. Transfection and assays were performed in triplicate and luciferase activity was normalized for $\beta$-galactosidase activity. Data are reported as relative light units.

\section{Real-time RT-PCR}

Total RNA was extracted from cells using Trizol according to the manufacturer's instructions (Invitrogen) and cDNA was synthesized using the multiscribe reverse transcriptase kit (Applied Biosystems, Foster City, CA, USA). The following Taqman probes and primers were used: ER $\beta$ forward (GACGACAAGGGCAAATGTGTT), reverse (AACTGGCGATGGACGACTAAA), probe (6 FAMTGGGCAACACGTGGGGACGTTTG). $\mathrm{ER} \beta$ mRNA levels were normalized to $\beta 2-$ microglobulin and $18 \mathrm{~S}$ mRNA levels using probes obtained from Applied Biosystems.

\section{Results}

\section{ERß protein level in MCF-7 and HeLa cells is sensitive to ligand}

All of the known breast cancer cell lines exhibit only very low endogenous ER $\beta$ protein levels. To examine $\operatorname{ER} \beta$ protein stability in MCF-7 cells, we transiently transfected ER $\alpha$-positive MCF-7 cells with the ER $\beta$ expression vector phER $\beta w t$, expressing the full-length receptor (530 amino acids). Transfected MCF-7 cells were grown for $24 \mathrm{~h}$ in the absence and presence of the ligand, and cell extracts were analyzed by immunoblotting (Fig. 1A). In the absence of ligand, moderate expression of $\mathrm{ER} \beta$ was detected. In the presence of $\mathrm{E} 2$, the apparent protein level of $\mathrm{ER} \beta$ was slightly lower. In contrast, treatment with either Tam or ICI 182,780 caused an increase of $\operatorname{ER} \beta$ protein.

Similar results were obtained in ER-negative HeLa cells (Fig. 1B), which suggested that the observed effect is not cell-type specific. To exclude the possibility that the ligand-mediated effects are due to a regulation of mRNA level, we performed RT-PCR analysis on total RNA extracted from the same treated cells as were used for the Western blot analysis (Fig. 1C). No significant changes in ER $\beta$ mRNA level were observed in the different treatment groups, which indicated that the ligand-dependent effects on ER $\beta$ are mediated at the post-transcriptional level. Our results suggested that ICI 182,780 and Tam increase the stability of $\mathrm{ER} \beta$ protein.

\section{Lactacystin and PI do not block ERß degradation in MCF-7 or HeLa cells}

In order to assess the potential involvement of the proteasome-mediated pathway in ER $\beta$ degradation, we evaluated the effects of specific and non-specific inhibitors of this pathway on ER $\beta$ stability (Fig. 2). In agreement with previous data (Dick et al. 1997, El Khissiin \& Leclercq 1999), lactacystin and PI, highly specific proteasome inhibitors, abrogated ER $\alpha$ degradation in MCF-7 cells transiently transfected with the ER $\beta$ expression vector (Fig. 2A) and in HeLa cells cotransfected with the $\mathrm{ER} \beta$ and $\mathrm{ER} \alpha$ expression vectors (Fig. 2B) significantly in the presence of E2. Interestingly, lactacystin and PI also increased the $\mathrm{ER} \alpha$ pool in the absence of ligand.

In contrast to their action on ER $\alpha$, lactacystin and PI did not block ER $\beta$ turnover. In fact, the presence of the proteasome inhibitors was associated with an even stronger degradation of ER $\beta$ in the presence of E2 in MCF-7 and HeLa cells. In the absence of ligands, PI caused a slight decrease in ER $\beta$ protein level in MCF-7 cells. Insulin, a non-specific inhibitor of cellular proteolysis, failed to block estrogen-dependent ER $\alpha$ or ER $\beta$ degradation.

\section{Mutation of helix 12 alters the ligand-induced degradation profile of ERB}

Recent studies have shown that specific amino acid residues in helix 12 of $\mathrm{ER} \alpha$ affect the stable 

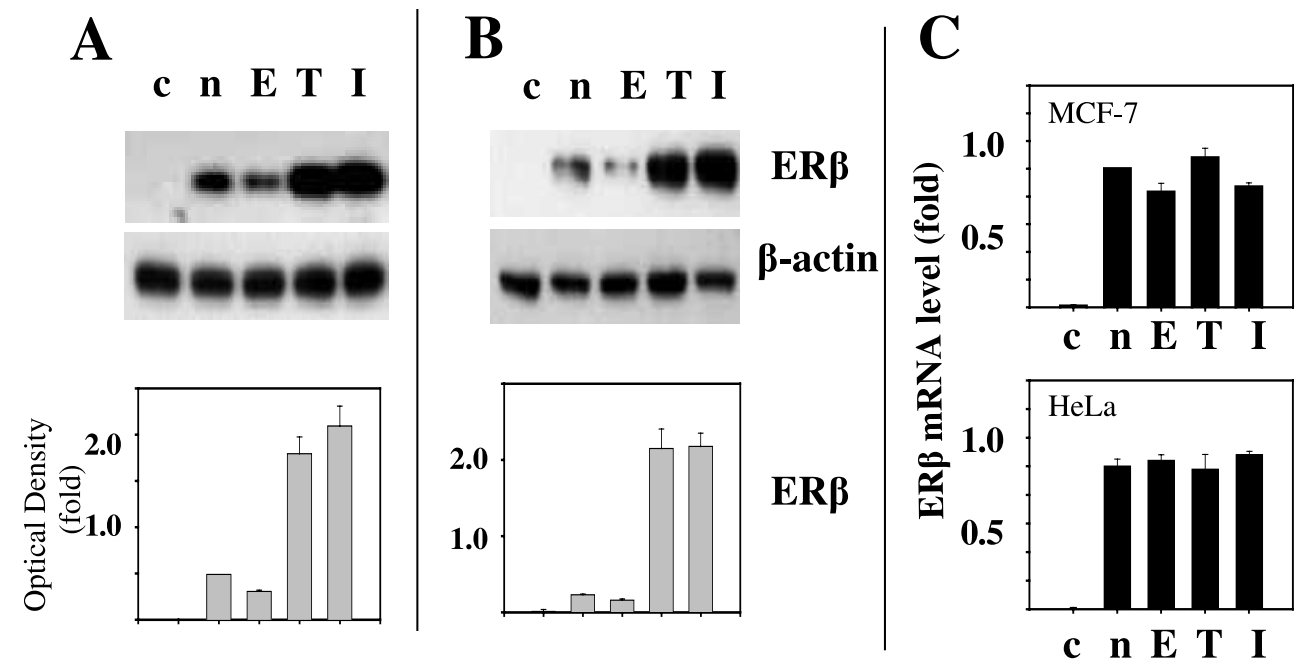

Figure 1 Protein and mRNA levels of ER $\beta$. Western blot of ER $\beta$ protein levels in (A) MCF-7 and (B) HeLa (B) cells. Cells were transiently transfected with control vector (c) or ER $\beta$ expression vector phER $\beta$ wt. Cells were treated with ethanol (EtOH) $(n), 10 \mathrm{nM}$ E2 $(\mathrm{E})$, Tam (T), or ICl 182,780 (I) for $24 \mathrm{~h}$. Western blot: equal amounts of cell extract $(10-20 \mu \mathrm{g})$ were loaded onto SDS-PAGE gels and analyzed by immunoblotting and densitometry. The level of ER $\beta$ protein in the graph is expressed as a ratio of ER $\beta$ to $\beta$-actin protein. (C) RT-PCR analysis of ER $\beta$ mRNA levels in MCF-7 and HeLa cells. Total RNA was extracted and RT-PCR was performed as described in Materials and methods. Three independent experiments were performed and the ratio of ER $\beta$ to $\beta 2$-microglobulin mRNA is shown.

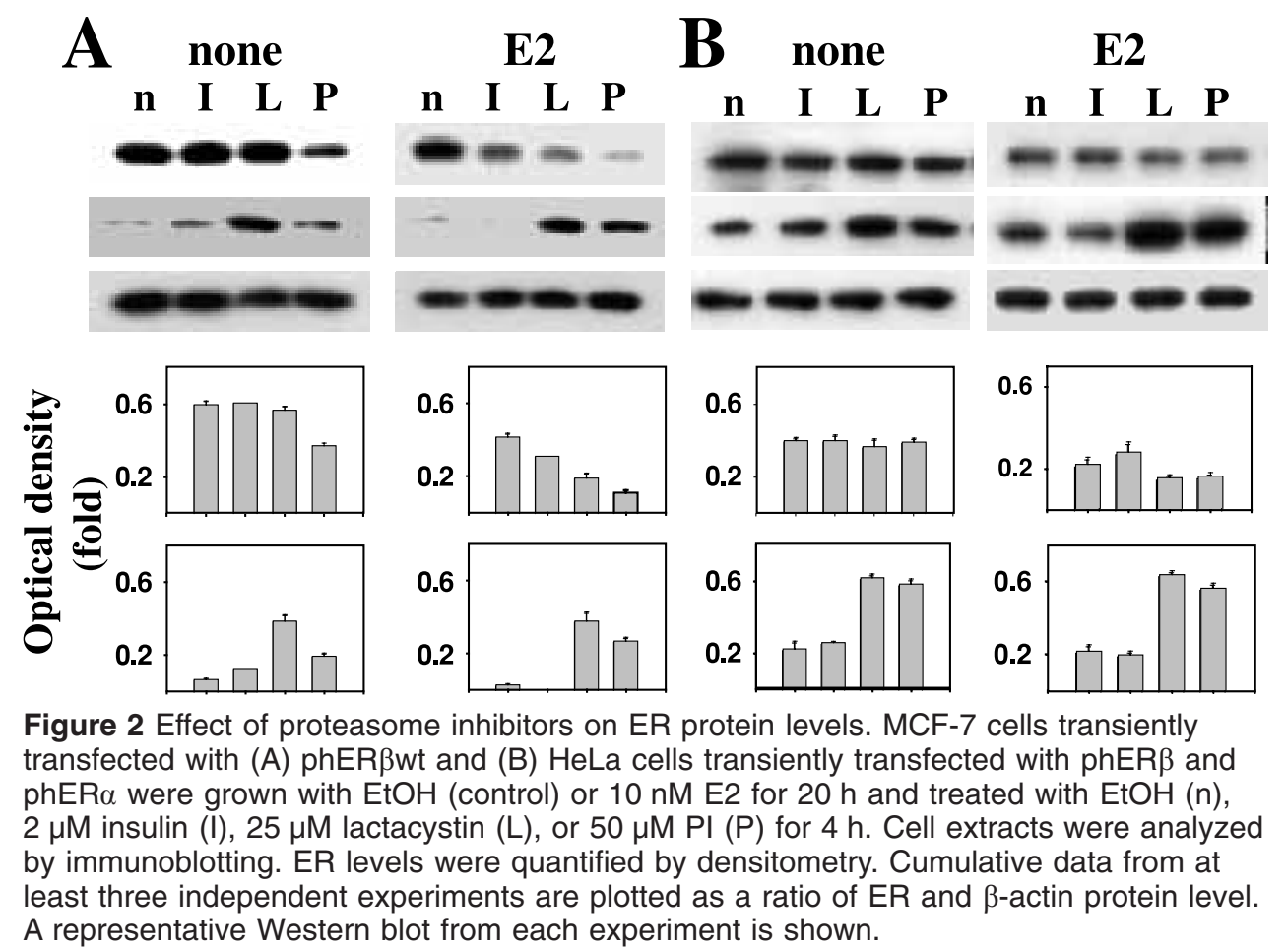


A

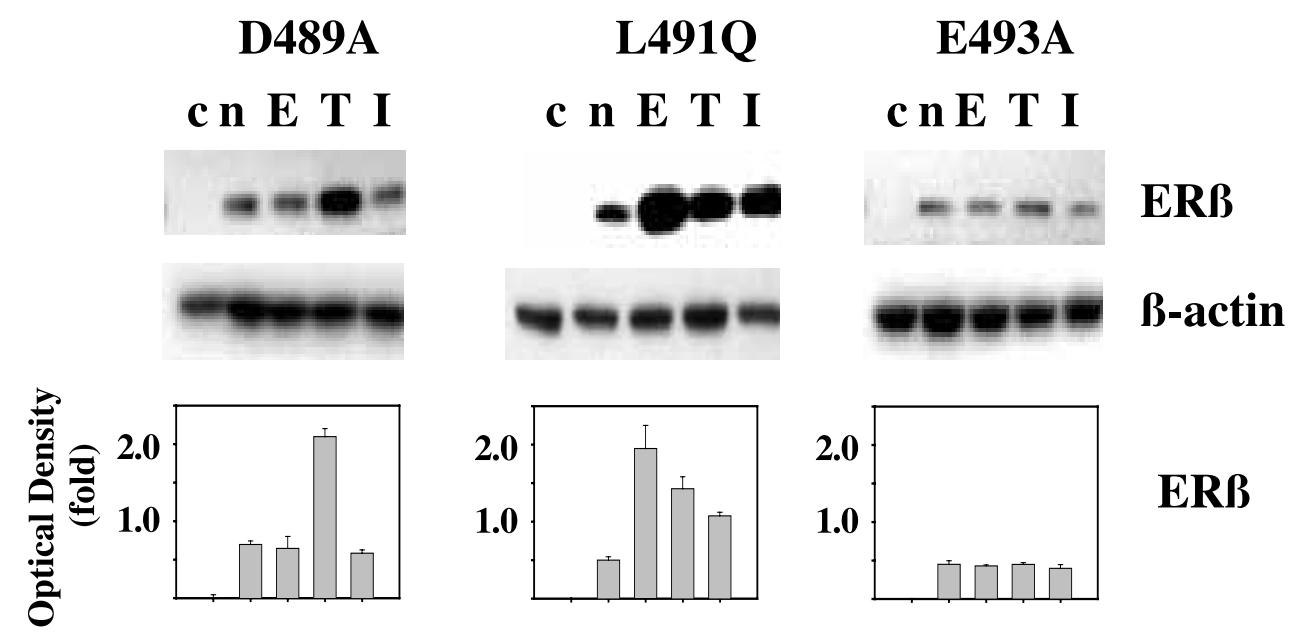

B
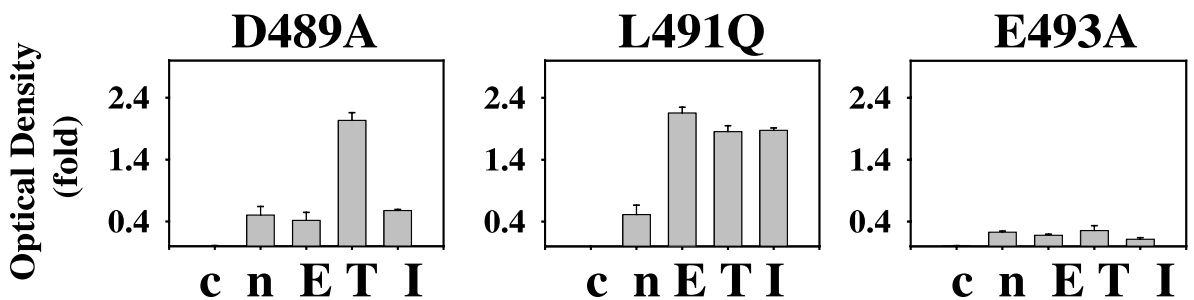

Figure 3 Western blot analysis of ER levels in ER $\beta$ mutants D489A, L491Q, and E493A in MCF-7 cells and HeLa cells. Cells were treated with EtOH (n), $10 \mathrm{nM}$ E2 (E), Tam (T), or ICI 182,780 (I) for 24 h; c, control vector. Western blot: equal amounts of cell extract were loaded onto an SDS-PAGE gel and analyzed by immunoblotting and densitometry. ER protein level was normalized to $\beta$-actin level. Data are presented as the means \pm S.D. of three independent experiments.

expression of the receptor (Mahfoudi et al. 1995, Pearce et al. 2003). To examine the role of those well-conserved sites in the regulation of $\operatorname{ER} \beta$ stability, we generated analogous mutants in $\operatorname{ER} \beta$ and tested these mutants with regard to their stability and activity in the presence of different ER ligands in MCF-7 and HeLa cells (Fig. 3). The E2and Tam-mediated stability of ER $\beta$ mutant D489A was similar to that of $\operatorname{ER} \beta$ wild type in both cell lines. However, this mutant showed enhanced ICI 182,780-mediated degradation. ER $\beta$ mutant L491Q, which is analogous to ER $\alpha$ L540Q, showed a different degradation profile compared with wild type. In this mutant, treatment with E2 increased
$\mathrm{ER} \beta$ protein to a level significantly higher than that with Tam or ICI 182,780. The expression of ER $\beta$ mutant E493A was low in untreated cells and remained unchanged with different ligands.

\section{ERß mutants exhibit different transcriptional activity of ERE and AP-1 reporter genes}

Previous studies have shown that, in mammary cells, ER $\alpha$ and $\operatorname{ER} \beta$ bind if complexed with estrogen directly to EREs within promoters and activate gene expression. In contrast, $\mathrm{ER} \alpha$ activates at AP-1 sites exclusively with estrogen and ER $\beta$ only with antiestrogens (Paech et al. 1997, Webb 

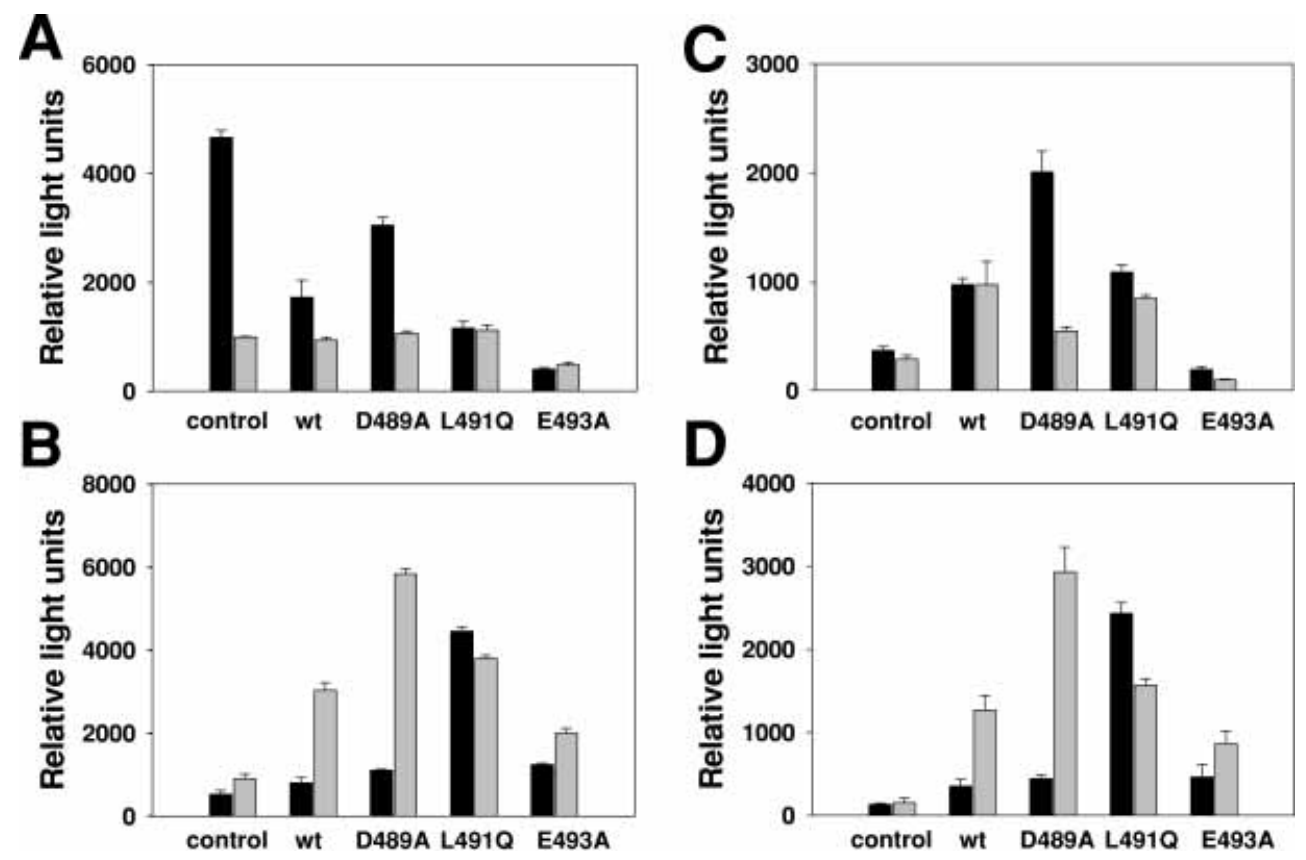

Figure 4 ER $\beta$ mutants display differential activation of ERE and AP-1 reporter. Expression of ( $A$ and $C$ ) synthetic ERE and (B and D) AP-1 luciferase reporter in ( $A$ and $C$ ) MCF-7 and (B and D) HeLa cells expressing wild type (wt) and mutant forms of ER $\beta$. Cells were transiently transfected with an ERE or AP-1-luciferase reporter plasmid, ER $\beta$ expression vector (wild type or mutant form) or control vector, and normalizing $\beta$-galactosidase vector. Cells were grown for $24 \mathrm{~h}$ in the presence of $10 \mathrm{nM}$ E2 (solid bars) or $10 \mathrm{nM}$ Tam (shaded bars) and luciferase activity was measured in crude extracts. Data are presented as the means \pm S.E. of three independent experiments. ${ }^{\star} P<0.05$ compared with control.

et al. 1999). We evaluated the effects of the ER $\beta$ mutations on the transcriptional activity of ER $\beta$ using an ERE as well as an AP-1-luc reporter gene construct containing three synthetic ERE or AP-1 sites respectively (Fig. 4).

In agreement with previous results, estrogen showed a more than fourfold ER $\alpha$-mediated induction of ERE in MCF-7 cells (Fig. 4A). In cells transiently transfected with $\mathrm{ER} \beta$ expression vector the induction by estrogen was less than twofold. These results are similar to previous results where $\mathrm{ER} \alpha$ was more transcriptionally active than $\mathrm{ER} \beta$, which acts as a trans-dominant modulator of ER $\alpha$ (Liu et al. 2002). Only a basal ERE induction was detected in HeLa cells transfected with the control vector (Fig. 4G). All three ER $\beta$ mutants showed a distinct phenotype regarding the activation at ERE, which was similar in both cell lines. Mutation D489A caused an 2.5-fold and fourfold increases in estrogen-dependent induction compared with the ER $\beta$ wild type in MCF-7 and HeLa cells respectively. In contrast, mutation E493A exhibited a strong decrease in transcriptional activation of the ERE reporter gene. Mutation L491Q had no significant effects on ER $\beta$ activity in both cell lines.

In contrast to E2, Tam showed a strong induction of the AP-1-luc reporter in the presence of ER $\beta$ (Fig. 4B and D), which is in agreement with previous results (Paech et al. 1997). ER $\beta$ mutation D489A caused a significantly higher induction of AP-1 with Tam compared with ER $\beta$ wild type and only a slight increase in the presence of E2. This is in sharp contrast to the effect of the analogous mutation (D538A) in ER $\alpha$, which lacked any estrogenic responsiveness to Tam (Table 1) (El Khissiin \& Leclercq 1999). Interestingly, ER $\beta$ mutant L491Q showed a six- and eightfold induction of transcription at AP-1 in the presence of E2, compared with wild type, in MCF-7 and HeLa cells respectively. The AP-1 activation of mutant E493A was similar to that of the wild type with E2 and Tam in both cell lines. 
Table 1 Stability of homologous ER $\beta$ and ER $\alpha$ mutants. The protein levels of ER $\beta$ (this study) and ER $\alpha$ (stable transfectants of MDA-MB-231 cells; adapted from Pearce et al. (2003)) wild type (wt) and mutants in the presence of none, E2, Tam or ICl 182,780 were compared (+++: highest, ++: modest, +: lowest level)

\begin{tabular}{|c|c|c|c|c|c|c|c|c|}
\hline & $\begin{array}{l}E R \alpha^{*} \\
\text { wt }\end{array}$ & $\begin{array}{l}\text { ER } \beta \\
\text { wt }\end{array}$ & $\begin{array}{l}\text { ER } \alpha^{*} \\
\text { D538A }\end{array}$ & $\begin{array}{l}\text { ER } \beta \\
\text { D489A }\end{array}$ & $\begin{array}{l}E R \alpha^{*} \\
\text { L540Q }\end{array}$ & $\begin{array}{l}\text { ER } \beta \\
\text { L491Q }\end{array}$ & $\begin{array}{l}E R \alpha^{*} \\
\text { E542A }\end{array}$ & $\begin{array}{l}\text { ER } \\
\text { E493A }\end{array}$ \\
\hline None & ++ & + & + & + & +++ & + & ++ & + \\
\hline E2 & + & + & + & + & +++ & +++ & ++ & + \\
\hline Tam & +++ & +++ & + & +++ & +++ & ++ & ++ & + \\
\hline $\mathrm{ICl}$ & - & +++ & - & + & +++ & ++ & + & + \\
\hline
\end{tabular}

*1 nM E2; 1 HM Tam or ICI 182,780 (ICI).

\section{Discussion}

One of the novel findings of this study was that the pure antagonist ICI 182,780 caused a stabilization of ER $\beta$ in MCF-7 and HeLa cells. The ability of ICI 182,780 to promote stable expression of $\operatorname{ER} \beta$ stands in contrast to its ability to promote degradation of ER $\alpha$ (Gibson et al. 1991, Dauvois et al. 1992). ICI 182,780 was found to decrease the half-life of ER $\alpha$ from $4-5 \mathrm{~h}$ to $0.5 \mathrm{~h}$ (Gibson et al. 1991, Dauvois et al. 1992), whereas Tam increased the half-life of ER $\alpha$. It is well documented that $\mathrm{ER} \alpha$ degradation is mediated via a proteasomemediated pathway in which $\mathrm{ER} \alpha$ is ubiquitinated and degraded by the $26 \mathrm{~S}$ proteasome in an ATP-dependent reaction (Hershko \& Ciechanover 1998, Alarid et al. 1999, El Khissiin \& Leclercq 1999).

It has been shown that the pattern and the extent to which ER $\alpha$ is ubiquitinated determine the rate at which the receptor is degraded (Wijayaratne \& McDonnell 2001). ICI 182,780-bound ER $\alpha$ was found to be the most heavily ubiquitinated, whereas Tam-bound ER $\alpha$ was the least ubiquitinated.

So far there are no data available regarding the stability of ER $\beta$ in vivo. However, in vitro proteolytic digestion analysis revealed that ER ligands have distinct effects on the conformation of both receptors, resulting in receptor subtype-selective opposite effects on receptor stability in vitro (Van Den Bemd et al. 1999). This suggests that there may be fundamental differences in the mechanism by which both receptors are recognized by the protein degradation machinery when complexed with the ligands.

It was shown that specific inhibitors of the proteasome-mediated pathway, like lactacystin and PI, are able to block ER $\alpha$ turnover (Dick et al.
1997). A recent study showed that lactacystin is effective at inhibiting $\mathrm{ER} \alpha$ as well as $\mathrm{ER} \beta$ turnover in HUAEC cells (Tschugguel et al. 2003). We tested these inhibitors and found that they do not abrogate ER $\beta$ degradation of MCF-7 or HeLa cells. In fact, lactacystin and PI caused an even higher turnover of $\mathrm{ER} \beta$ in the presence of $\mathrm{E} 2$ in MCF-7 cells. In contrast, the inhibitors had no effects on ER $\beta$ stability in HeLa cells. However, the protein levels of ER $\beta$ under these conditions were overall very low. The data suggested that the mechanism of $\operatorname{ER} \beta$ degradation is likely to be different from that of $\operatorname{ER} \alpha$ and might not be mediated via the same proteasome-dependent pathway. Our results further suggest that inhibition of the ER $\alpha$-specific proteasome pathway may negatively affect ER $\beta$ stability in MCF-7 cells. Blockade of the proteasome pathway could lead to an increase of an unknown factor which decreases $\operatorname{ER} \beta$ stability.

Furthermore, we evaluated the effects of point mutations in helix 12 of $\operatorname{ER} \beta$ on the stability of the receptor (Dauvois et al. 1992). We found that some of the mutations changed the stability profile of the receptor. A key residue involved in ICI 182,780mediated stability of ER $\beta$ is D489 because mutation of this residue results in loss of protein stability in the presence of ICI 182,780. ER $\alpha$ D538A and E542A were both shown to have similar ligand-mediated modulating effects on receptor stability (Table 1) (El Khissiin \& Leclercq 1999). ER $\beta$ E493A showed reduced expression of $\mathrm{ER} \beta$ protein in the absence and presence of all tested ligands. This is in contrast to the analogous ER $\alpha$ mutation E542A, which showed only slightly reduced degradation with ICI 182,780 but wildtype-like stability in the presence of Tam (Table 1) (El Khissiin \& Leclercq 1999). Interestingly, the 
L491Q mutant displayed E2-mediated stabilization of ER $\beta$ expression. Together these observations support and extend the idea that helix 12 plays a major role in the regulation of the stability of ER $\alpha$ and ER $\beta$. D489 and L491 appear to be directly or indirectly involved in the recognition and degradation of the ER $\beta$ receptor-ligand complex.

We also tested the effect of those mutants on the transcriptional activity of the receptor to activate an ERE and AP-1-luc reporter (Fig. 4). In agreement with previous results (Paech et al. 1997, Webb et al. 1999), we observed that ER $\beta$ expression in MCF-7 cells caused a three- to fourfold induction of the AP-1-luc reporter by Tam (Fig. 4B). Expression of ER $\beta$ in MCF-7 cells resulted also in a strong decrease in the ER $\alpha$-mediated ERE activation (Fig. 4A). This can be explained by the lower transcriptional activity of ER $\beta$ compared with $\mathrm{ER} \alpha$ at the ERE site (Liu et al. 2002). Mutant D489A showed a sixfold increase in activation at AP-1 response elements in the presence of Tam. In contrast, in the presence of estrogen this mutant exhibited a significantly higher activation of an ERE reporter compared with ER $\beta$ wild type. Further, mutant L491Q, which was stabilized by E2, was able to activate the AP-1 reporter with E2 fivefold (Fig. 4B). However, this mutation had no effect on ERE activation. Mutation E493A showed, in contrast to the homologous mutation in ER $\alpha$, a strong effect on the transcriptional activation of an ERE reporter. The ER $\beta$ mutation caused a threefold decrease in estrogen-mediated activation and a twofold decrease with Tam (Fig. 4A). Therefore, mutations in helix 12, which increased the stability of $\mathrm{ER} \beta$, also increased its transcriptional activity. This pattern of activation correlates with the increased stability of ER $\beta$ under these conditions and shows that ligand-mediated stability and transcriptional activity are linked.

\section{Acknowledgements}

We thank Azriel Schmidt (Merck Research Laboratories) for kindly supplying the AP-1 reporter plasmid and for his helpful suggestions.

\section{References}

Alarid ET, Bakopoulos N \& Solodin N 1999 Proteasome-mediated proteolysis of estrogen receptor: a novel component in autologous down-regulation. Molecular Endocrinology 13 1522-1534.
Couse JF, Dixon D, Yates M, Moore AB, Ma L, Maas R \& Korach KS 2001 Estrogen receptor- $\alpha$ knockout mice exhibit resistance to the developmental effects of neonatal diethylstilbestrol exposure on the female reproductive tract. Developmental Biology 23 8224-8238.

Cowley SM, Hoare S, Mosselman S \& Parker MG 1997 Estrogen receptors alpha and beta form heterodimers on DNA. Journal of Biological Chemistry 272 19858-19862.

Dauvois S, Danielian PS, White R \& Parker MG 1992 Antiestrogen ICI 164,384 reduces cellular estrogen receptor content by increasing its turnover. PNAS 89 4037-4041.

Dick LR, Gruiksshank AA, Destree AT, Grenier L, McCormack TA, Melandri FD, Nunes SL, Palombella VJ, Parent LA, Plamondon L et al. 1997 Mechanistic studies on the inactivation of the proteasome by lactacystin in cultured cells. Fournal of Biological Chemistry 272 182-188.

El Khissiin AE \& Leclercq G 1999 Implication of proteasome in estrogen receptor degradation. FEBS Letters 448 160-166.

Frasor J, Barnett DH, Danes JM, Hess R, Parlow AF \& Katzenellenbogen BS 2003 Response-specific and ligand dose-dependent modulation of estrogen receptor (ER) $\alpha$ activity by ER $\beta$ in the uterus. Endocrinology 144 3159-3166.

Gibson MK, Nemmers LA, Beckman WC, Davis VL, Curtis SW \& Korach KS 1991 The mechanism of ICI 164,384 antiestrogenicity involves rapid loss of estrogen receptor in uterine tissue. Endocrinology 129 2000-2010.

Hall JM \& McDonnell DP 1999 The estrogen receptor beta-isoform (ERbeta) of the human estrogen receptor modulates ERalpha transcriptional activity and is a key regulator of the cellular response to estrogens and antiestrogens. Endocrinology 140 $5566-5578$.

Hershko A \& Ciechanover A 1998 The ubiquitin system. Annual Review of Biochemistry 67 425-479.

Hewitt SC \& Korach KS 2003 Oestrogen receptor knockout mice: roles for oestrogen receptors $\alpha$ and $\beta$ in reproductive tissues. Reproduction 125 143-149.

Katzenellenbogen BS \& Katzenellenbogen JA 2000 Estrogen receptor transcription and transactivation: estrogen receptor alpha and estrogen receptor beta: regulation by selective estrogen receptor modulators and importance in breast cancer. Breast Cancer Research 2 335-344.

Katzenellenbogen BS, Montano MM, Ediger TR, Sun J, Ekena K, Lazennec G, Martini PG, Delage-Mourroux R, Weis K \& Katzenellenbogen JR 2000 Estrogen receptors: selective ligands, partners, and distinctive pharmacology. Recent Progress in Hormone Research 55 163-193.

Kuiper GGJM, Enmark E, Petto-Huikko M, Nilson S \& Gustafsson J-A 1996 Cloning of a novel receptor expressed in rat prostate and ovary. PNAS 93 5925-5930.

Lazennec G, Bresson D, Lucas A, Chauveau C \& Vignon F 2001 $\mathrm{ER} \beta$ inhibits proliferation and invasion of breast cancer cells. Endocrinology 142 4120-4130.

Lindberg MK, Moverare S, Skrtic S, Gao H, Dahlman-Wright K, Gustafsson J-A \& Ohlsson C 2003 Estrogen receptor- $\beta$ reduces estrogen receptor- $\alpha$ regulated gene transcription, supporting a 'ying-yang' relationship between estrogen receptor $\alpha$ and $\beta$ in mice. Molecular Endocrinology 17 203-208.

Liu M-M, Albanese C, Anderson CM, Hilty K, Webb P, Uht RM, Price RH, Pestell RG \& Kushner PK 2002 Opposing action of estrogen receptors $\alpha$ and $\beta$ on cuclinD1 gene expression. Fournal of Biological Chemistry 277 24353-24360.

Mahfoudi A, Roulet E, Dauvois S, Parker MG \& Wahli W 1995 Specific mutations in the estrogen receptor change the properties of antiestrogens to full agonists. PNAS 92 4206-4210.

Paech K, Webb P, Kuiper GG, Nilson S, Gustafsson J, Kushner PJ \& Scanlan TS 1997 Differential ligand activation of estrogen receptors ERalpha and ERbeta at AP-1 sites. Science 277 $1508-1510$ 
Pearce ST, Liu H \& Jordan VC 2003 Modulation of estrogen receptor $\alpha$ function and stability by tamoxifen and a critical amino acid (Asp-538) in helix 12. Fournal of Biological Chemistry 278 $7630-7638$

Pettersson K, Delaunay F \& Gustafsson JA 2000 Estrogen receptor beta acts as a dominant regulator of estrogen signaling. Oncogene 19 4970-4978.

Preisler-Mashek MT, Solodin N, Stark BL, Tyriver MK \& Alarid ET 2002 Ligand-specific regulation of proteasome-mediated proteolysis of estrogen receptor-alpha. American Journal of Physiology 282 E891-E898.

Read LD, Greene GL \& Katzenellenbogen BS 1989 Regulation of estrogen receptor ribonucleic acid and protein levels in human breast cancer cell lines by sex steroid hormones, their antagonists, and growth factors. Molecular Endocrinology 3 295-304.

Tschugguel W, Dietrich W, Zhegu Z, Stonek F, Kolbus A \& Huber JC 2003 Differential regulation of proteasome-dependent estrogen receptor alpha and beta turnover in cultured human uterine artery endothelial cells. Fournal of Clinical Endocrinology and Metabolism 88 2281-2287.

Van Den Bemd G-JCM, Kuiper GGJM, Pols HAP \& Van Leeuwen JPDM 1999 Distinct effects on the conformation of estrogen receptor alpha and beta by both the antiestrogens ICI 164,384 and ICI 182,780 leading to opposite effects on receptor stability. Biochemical and Biophysical Research Communications 261 1-5.

Webb P, Nguyen P, Valentine C, Lopez GN, Kwok GR, McInerney E, Katzenellenbogen BS, Enmark E, Gustafsson JA, Nilson S et al. 1999 The estrogen receptor enhances AP-1 activity by two distinct mechanisms with different requirements for receptor transactivation functions. Molecular Endocrinology 13 1672-1685.

Weihua Z, Saji S, Makinen S, Cheng G, Jensen EV, Warner M \& Gustafsson JA 2000 Estrogen receptor- $\beta$, a modulator of ERalpha in the uterus. PNAS 97 5936-5941.

Wijayaratne AL \& McDonnell DP 2001 The human estrogen receptor-alpha is a ubiquitinated protein whose stability is affected differentially by agonists, antagonists, and selective estrogen receptor modulators. Fournal of Biological Chemistry 276 35684-35692.

Received 31 December 2003 Accepted 30 March 2004 